\title{
Evaluating the Translation of Accusative of Purpose by EFL learners
}

\author{
Intisar Hassan Abdul Magid Mohammad \\ Assistant Professor, Alkhafji University College, University of Hafr Al Batin, Saudi Arabia \\ $\triangle$ Corresponding Author: Intisar Hassan Abdul Magid Mohammad, E-mail: Intsar22@hotmail.com
}

\section{ARTICLE INFORMATION ABSTRACT}

Received: December 19, 2020

Accepted: February 18, 2021

Volume: 4

Issue: 2

DOI: $10.32996 /$ ijllt.2021.4.2.20

\section{KEYWORDS}

Accusative, spoken Semitic language, Modern Standard Arabic, translation process, Arabic and English
Arabic is the most widely spoken Semitic language and has seen phases of change from the Quranic form to the more popular Modern Standard Arabic that is used for communication today. Teachers of language and translation in KSA are concerned with learning problems that arise due to lexical and grammatical non-equivalence between Arabic and English which often leads to confusion and incorrect output during translation process. The current study aimed at investigating one of the Arabic grammatical structures which has no direct equivalent in English (Accusative of Purpose). It is an original noun derived from a verb of affectivity, explaining the reason why the action of the previous verb has been done. Two objectives were targeted: One, testing the learners' ability to translate the Accusative of Purpose; and two, to gather an understanding of the strategies they adopted in the process. The study is likely to be of great value in a foreign language learning environment as is the case in the KSA. We used written tests to collect the data, followed by detailed interviews to elicit information on the translation strategies used. Participants were female undergraduate students $(\mathrm{N}=35)$ at Hurimilla College of Science and Humanities, Shaqra University, KSA, of which fifteen were randomly interviewed consequently. Both qualitative and quantative approaches were used. The data collected was analysed using SPSSR. The results revealed that (36.0\%) of the students' translations were correct or acceptable, while $34.3 \%$ were literal, and (15.4\%) were incorrect. Personal interviews revealed that reasons of these results can be attributed to the absence of this category in English, and non-equivalence between Arabic and English. Based on these findings, the present study suggests more investigations on similar Arabic structures which have no correspondence in English using larger number of participants.

\section{Introduction}

Translation is as much an essential component of human communication as the very production of speech in the first place. Moreover, given the changing face of human interaction in the world, it has assumed the status of an important element for the exchange of information, thoughts, and ideas regardless of people's different tongues and cultures. Apart from a communication tool, translation has an undeniable place in foreign language teaching and testing. Azziz and Lataiwish (2000, p.166) point out that translation is has been an integral part of academics, and it has been widely practiced throughout the course of human language. Hence the growing worth of translation studies which is also the beacon light that guided the current study in Contrastive Linguistics.

Contrastive linguistics is considered one of the new fields within translation studies. It involves the analysis of two or more languages, with the aim of understanding their similarities and differences. The objectives of the comparison may vary. The term 'contrastive linguistic' or 'contrastive analysis', specially concerns itself with the applied aspects of contrastive studies as a means of predicting and/or explaining difficulties of second language learners with a particular mother tongue in learning a target language. Contrastive studies in translation do not only concentrate on texts but also investigate even the smaller units in

K C AL-KINDI CENTER R D FOR RESEARCH AND OEVELOPMENT Your gateway to world-class research

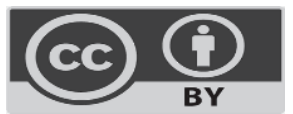

Published by Al-Kindi Center for Research and Development. Copyright (c) the author(s). This open access article is distributed under a Creative Commons Attribution (CC-BY) 4.0 license 
languages, such as, grammatical and lexis. Williams and Chesterman (2002, p. 90) highlight this fact when they state, "A contrastive approach might also focus not on texts but on grammatical structures or lexical items, looking for equivalence rules for translating certain structures between a given pair of languages, or for terminology equivalents".

\subsection{Statement of the Problem}

As teachers of translation courses, we understand the particularly challenging task that is translation. Whether identified as a science or an art, the pitfalls associated with it still remain. Translation teachers (at least in the KSA) are conscious of sensitizing their students to the fact that meaning is embedded in context, that language can sometimes be restrictive, and that precise language equivalents sometimes do not exist. Equivalence or its absence is a known hurdle in translation. The problem arises when suitable counterparts in a target language do not exist for expressions in the source language. Non- equivalence, predictably, is one of the obstacles that face both translators and students of English. Arabic has many structures that do not exist in English such as Accusative المَفعولٌ لاجله Purpose. Therefore, when students encounter such structures, they feel confused. Translating to and from English-Arabic therefore poses a peculiar, though not unique, challenge for them. English and Arabic belong to different language families and are even written in different directions. One of the main features of nonequivalence, and one which is also the focus of this study, is the accusative case. Syntactically, the object in Arabic appears in the accusative case but its semantic function may vary from emphasis to indication of any of the many aspects of an event. This embedded feature is seen by Arabic speaking learners of English as a major hurdle in translation. This problem has been previously studied but the current research aims to add the dimension of learner strategies employed to counter it.

\subsection{Study Questions}

1- Which strategies do the students resort to when translating Accusative of Purpose to English?

2- What are the reasons for using these strategies to translate this structure?

\subsection{Research Objectives}

The study had the following objectives to achieve:

(a) Create an understanding among those engaged in learning and doing translation about the possible linguistic challenges that they may have to encounter.

(b) Create greater awareness among the linguists and translators towards undertaking descriptive bilingual comparative studies in the study of translation between Arabic and English.

\section{Literature Review}

Contrastive studies of English and Arabic are numerous with a long history. These came into vogue more than half a century ago in the late 1950s (Mukattash, 2001, p.115) Elwedyanicf as quoted in Abu-Jarad reports of a study conducted by Catford. This extensive study included phonology, morphology, and syntax. According to AbuJarad (1986, p.18) Native language interference, TL overgeneralization and fossilization were likely to occur in case of translation between Arabic and English.

Mukattash, (2001,p.116) pinpoints the following titles that investigate different issues in English-Arabic contrastive studies in the last five years: "Verb movement, subject movement and word order in English and Arabic", "Locative attention in English and Jordanian spoken Arabic", "Negation in Cairene colloquial Arabic, English and French: an historical linguistic analysis", "Syntactic devices for marking information structure in English and Arabic", and "Lexical, phonological and textual features of English and Arabic advertisements: a contrastive study."

\subsection{Traditional Arabic versus Modern Standard Arabic}

In modern times, two standard (al-)fuṣhá (الفصحى) varieties of Arabic are recognised: the Classical Arabic (CA) (لعربية اللغة (7th) اللغة العربية (1) as found in the Quran and early Islamic (7th to 9th centuries) literature, and Modern Standard Arabic (MSA) التراثة ( the standard language of use today. MSA is based on classical Arabic, and the differences between the two varieties of the language are lies in the modernizing and simplification, both in speaking and writing styles to be seen in MSA. However, the two are not seen as separate entities, rather as two registers.

Accusative (حالة النصب) in Arabic are nouns used as object in sentences, and their modifying adjectives. Nouns that are accusative are called (المنصوب) in Arabic. The number, gender and definiteness of the noun or adjective in question are marked using inflections in Arabic. This makes Arabic a highly inflectional language.

There are five types of objects or complements, المفعول فيه ,المفعول لأجله ,المفعول المطلق المفعول معه,المفعول به,Dahdah, (2001, p.237) 
1. المفعول به - The object of a transitive verb

نار is nunated because it is indefinite. It has an (alif) because it ordinarily would have a regular (fatHa), and doesn't end in a (taamarbuuTa) or (hamza).

اجتاز الطلاب الامتحانَ "The Students passed the exam".

Adverbial expressions of time, place, and manner, indicating the circumstances under which an action takes place.

. I arrived in Baghdad at night".

Flowers bloom in spring.

. recently obtained citizenship".

The internal object or cognate accusative structure. This structure intensifies an action by following the verb with its corresponding verbal noun (مصدر maSdar) and an adjective modifying it.

هرثنا الارض حرثا. :We did plough the land".

ساهما مساهمةً فعّالة. : "They [dual] participated effectively".

الحال - The circumstantial accusative. This is a way to describe a condition/action going on at the same time as the main action.

رفع يده معترضا.

"The army came victorious".

مصدر shows the purpose of an action, usually using an indefinite - المفعول لأجله

"لاتقتلوا أولادكم خشية املاق الاقله - Don't kill your children for fear of poverty".

"I stood to honour my father".

- The accusative of specification; often answers the question "in what way?" Includes the comparative/superlative and counted nouns between 11 and 99 .

"We announce that in speech and action".

"It was the greatest capital in fame and splendor.

"in twenty volumes"

على مدى خمسةً عشر عاما مجام "for fifteen years".

These are the main ways in which the accusative is used in Arabic. There are also other, special words that shift words into the accusative case:

كان وأخواتها - إنّ وأخواتها - ظنّ وأخواتها

\subsection{Accusative of Purpose}

It is an accusative noun which shows the reason of the action (Abd-Almouaine, 2004, p. 496). It is the answer of the following question: why does the agent do the action? (Al-Dahdah, 2001). For example, in غسلت ملابس أختي مساعدة لها l washed my sister's clothes to help her) is an indefinite, singular verbal noun in the accusative case. It gives information about why the action/verb is done or shows the motive, purpose, or reason for an action. It can always be an answer to the question word Iاذما. Consider the following sentences:

The students stood up.

Why did the students stand up?

The students stood up in respect for the teacher.

However, this Arabic eloquent structure can either be:

1. The Accusative of Purpose is basically an indefinite noun in the accusative state with the accusative sign, for example:هربت =خوفا (I fled out of fear.) This is usually the case when the infinitive does not have الف ام ام prefixed to another word. Here are more Examples:

\begin{tabular}{|c|c|c|}
\hline Accusative of Purpose & English Equivalent & Arabic Sentence \\
\hline حُبًَا & $\begin{array}{l}\text { I read the story out of love for its } \\
\text { writer }\end{array}$ & 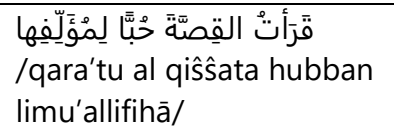 \\
\hline طَاعَةً & I pray to obey my God & $\begin{array}{l}\text { أُصِلِي طَاعَةً لِرَبِّي } \\
\text { /uŝallī aâzatan lirabbī/ }\end{array}$ \\
\hline بِرَّا & $\begin{array}{l}\text { I help my mother for filial } \\
\text { obedience }\end{array}$ & 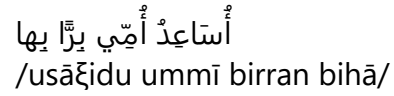 \\
\hline
\end{tabular}




\begin{tabular}{|c|c|c|}
\hline أَمَلاً & $\begin{array}{l}\text { I played and endured hopping to } \\
\text { win }\end{array}$ & 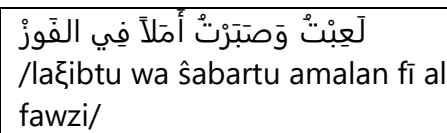 \\
\hline طَلَبَا & I travelled asking for freedom & $\begin{array}{l}\text { سافَرْتُ طَلَبًَا لِلْحُرِيَيَّةِ } \\
\text { /sāfartu talaban lil hurriyyati/ }\end{array}$ \\
\hline قَصْدَا & $\begin{array}{l}\text { I ask the scientists seeking for } \\
\text { knowledge }\end{array}$ & 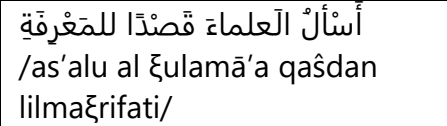 \\
\hline
\end{tabular}

In the accusative state with the genitive sign, for example:ضربت ولدي لتاديبه (I hit my son to teach him manners.) This is usually the case when the infinitive does have الف لام and is prefixed to another word.

\begin{tabular}{|c|c|}
\hline I travelled desiring to perform pilgrimage & 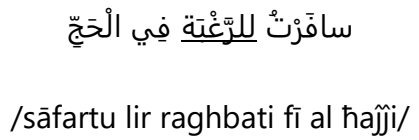 \\
\hline I came here to study (for studying) & $\begin{array}{l}\text { جْنْتُ للِدّرَاسَة } \\
\text { رَji'tu lid dirâsati/ }\end{array}$ \\
\hline
\end{tabular}

If the Accusative of Purpose is annexed to another noun, it is possible to be in the accusative case or to be in the genitive case after the preposition (ل) as in the following examples:

\begin{tabular}{|c|c|c|}
\hline English meaning & Genitive & Accusative \\
\hline And do not kill your children for fear of poverty & 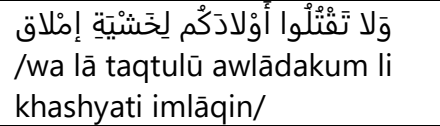 & $\begin{array}{l}\text { وَلا تَقْتُلُوا أَوْلادَكْم خَشْيَيَة إمْلاقاق } \\
\text { /wa lā taqtulū awlādakum } \\
\text { khashyata imlāqin/ }\end{array}$ \\
\hline I worship Allah for fear of His torment & 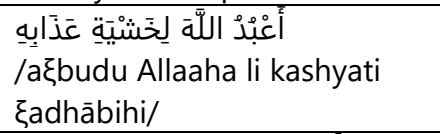 & 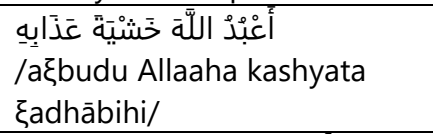 \\
\hline I spend the wealth seeking Allah's Countenance & 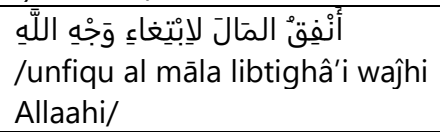 & 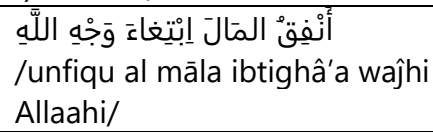 \\
\hline
\end{tabular}

Examples of Accusative of Purpose from the Holy Quran:-

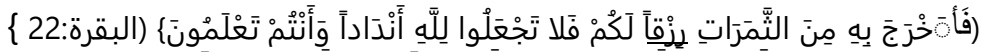

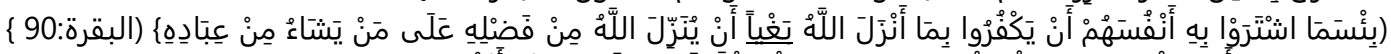

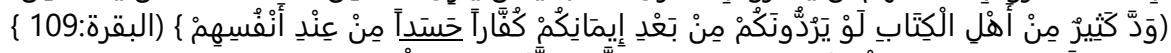

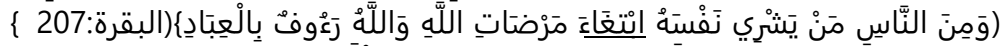

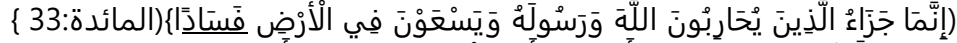

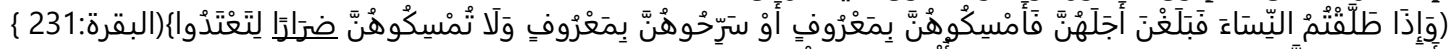

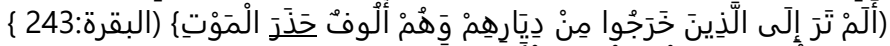

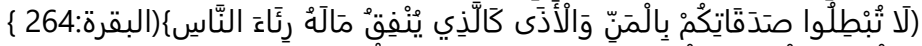

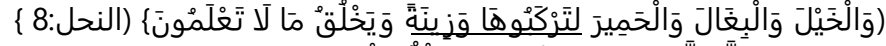

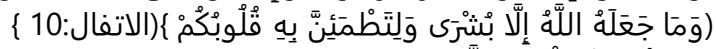

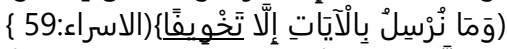

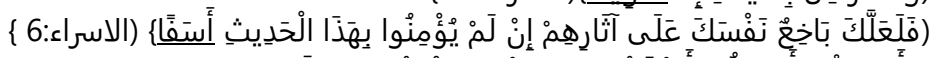

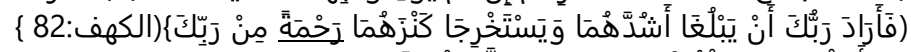

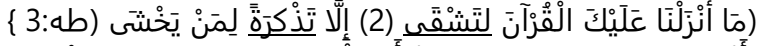

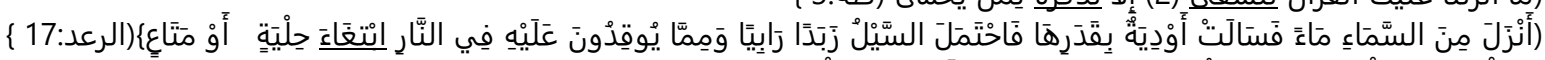

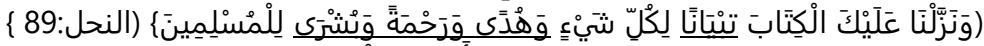

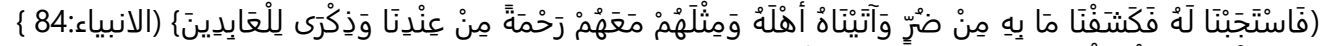

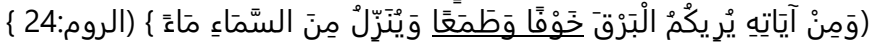




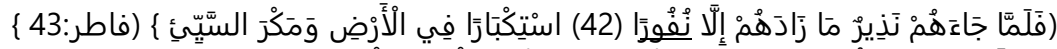

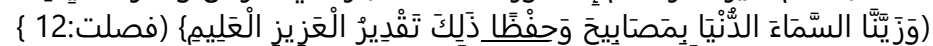

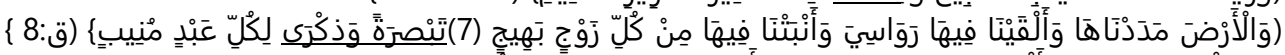

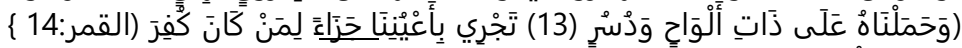

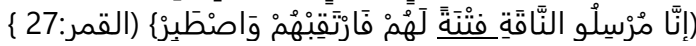

\section{Methodology}

We used the descriptive analytical method in this study. Both quantitative and qualitative methods were used to collect data from the selected participants, level six learners of translation who were administered a translation test comprising five Arabic sentences to be translated to English. The structures had the accusative of Purpose in different functions (Appendix 01). The actual number of the students enrolled in the course (translation 2) was (41). Six withdrew for different excuses. So, the study sample consisted of (35) undergraduate female students from the English language program at Hurimilla College of Science and Humanities, Shaqra University, KSA. One of the suggested fields of work for these students is translation. So, they are prepared, although with a few courses of translation, but intensive. Because it is a small province, the number of the females in different departments, particularly English is few.

All the students were females ranged between 18-23 years old. The number of students at this level is few as usually a great number of the students withdraw, or are transferred to other departments when they reach advanced stages in the home departments. EFL learners at this college receive three courses of translation. The first one is assigned in the first year (Level One) of the program, second term. It trains the students in English - Arabic translation. This course includes some theories in translation such as the principles of translation, types of translation etc, but it does not include any information about equivalence. Similarly, the second course which follows the first one also trains the students in translation from English into Arabic, neglects this notion. The last course is assigned to students in the third year (level six), second term when students' competence in English is fortified. According to the department curriculum, they receive just a single Arabic- English course. These students (academic year 1436-1437 H.D)/ Second Term) comprised the population of this study.

Following the test, fifteen of the respondents were randomly requested to answer questions on a one-to-one basis. The interview questions were centred around the obstacles faced by the respondents in translating to English.

\subsection{Procedures}

\subsubsection{Face Validity}

To establish face validity, the test was judged by four Arabic language assistant professors at Shaqra University. Their constructive comments and remarks were taken into consideration and the necessary modifications were made accordingly.

\subsubsection{Procedures of the Students' Test}

The participants were asked to translate (5) Arabic sentences into English at the beginning of the Arabic- English translation course. Out of context sentences were chosen for two purposes. Firstly, the test was conducted at the beginning of the term. The students usually start this course (Translation 2) by translating different types of sentences as an introduction before shifting to paragraphs or texts. Secondly, according to the researcher's experience, the students are rather slow in translating and they would have needed a longer time had paragraphs been chosen for the exercise. They were also likely to lose interest if the test was made too difficult or long. The test was graded out of 10 marks with two marks allocated for each sentence. The targeted participants were asked not to use any translation web sites or apps other than dictionaries to ensure that they will translate the sentences by themselves. The sentences have been taken from different sources such as books and specialized web sites.

Table (1): Criteria followed for marking the Students' Test

\begin{tabular}{|c|l|}
\hline Mark & \multicolumn{1}{|c|}{ Explanation } \\
\hline 2 & $\begin{array}{l}\text { The translation provided is correct or acceptable (It means that the student } \\
\text { translated the target structure correctly, or produced a good outcome). }\end{array}$ \\
\hline 1 & $\begin{array}{l}\text { The translation provided is literal (the student used the same part of speech of } \\
\text { the studied category. }\end{array}$ \\
\hline $11 / 2$ & $\begin{array}{l}\text { The translation provided is incorrect (the student avoided translating the target } \\
\text { or used a different grammatical category }\end{array}$ \\
\hline $1 / 2$ & $\begin{array}{l}\text { The translation provided is weak (the student's translation is semantically and } \\
\text { syntactically poor). }\end{array}$ \\
\hline zero & No translation is given at all. \\
\hline
\end{tabular}




\subsection{Reliability of the Test}

After distributing the test, reliability and validity were measured (Alpha Cronbach rule). In order to determine whether the entire test is consistent, Cronbach Alpha was conducted to ensure the reliability of the test. The higher the Alpha is, the more reliable the test is. Usually, 0.70 and above is acceptable.

Table (2): Reliability of the Test

\begin{tabular}{|c|c|c|c|c|}
\hline \\
\hline \multicolumn{3}{|c|}{ Accusative of purpose } & .808 & .793 \\
\hline \multicolumn{3}{|r|}{ ق قمت إكراما لأبي. } & .842 & .787 \\
\hline \multicolumn{3}{|r|}{ لم نزر المريض تجنبا لإزعاجه. } & .732 & .814 \\
\hline \multicolumn{3}{|r|}{ سال المدرس الطلاب عدة أسئلة اختبارا لمعرفتهم. } & .629 & .842 \\
\hline \multicolumn{3}{|r|}{ منح الجندي وساما تقديرا لأعماله العظيمة. } & .390 & .889 \\
\hline Cronbach's Alpha & 0.858 & & & \\
\hline \multicolumn{3}{|l|}{ All test .924} & & \\
\hline
\end{tabular}

\section{Findings and Discussion}

4.1 Analysis and Discussion of the Test المفعول لأجله

Table (3): Students' Marks of Translation in Accusative of Purpose

\begin{tabular}{|c|c|c|c|c|}
\hline Sentences regarding accusative of purpose & Freq. & Percent (\%) & \multirow{2}{*}{\multicolumn{2}{|c|}{ Mark Mean \pm SD }} \\
\hline \multicolumn{3}{|c|}{ يجتهد الطالب رغبة في النجاح } & & \\
\hline The translation provided is correct or acceptable (2) & 5 & 14.3 & \multirow{5}{*}{$1.16 \pm 0.48$} & \multirow{26}{*}{$6.61 \pm 2.56$} \\
\hline The translation provided is incorrect (1.5) & 6 & 17.1 & & \\
\hline The translation provided is literal (1) & 21 & 60.0 & & \\
\hline The translation provided is weak (.5) & 1 & 2.9 & & \\
\hline No translation is given at all $(0)$ & 2 & 5.7 & & \\
\hline \multicolumn{3}{|c|}{ ق قمت إكراما لأبي. } & & \\
\hline The translation provided is correct or acceptable(2) & 9 & 25.7 & \multirow{5}{*}{$1.20 \pm 0.63$} & \\
\hline The translation provided is incorrect (1.5) & 7 & 20.0 & & \\
\hline The translation provided is literal (1) & 11 & 31.4 & & \\
\hline The translation provided is weak (.5) & 5 & 14.3 & & \\
\hline No translation is given at all $(0)$ & 3 & 8.6 & & \\
\hline \multicolumn{3}{|c|}{ لم نزرالمريض تجنبا لإزعاجه. } & & \\
\hline The translation provided is correct or acceptable(2) & 12 & 34.286 & \multirow{5}{*}{$1.34 \pm 0.62$} & \\
\hline The translation provided is incorrect (1.5) & 7 & 20.000 & & \\
\hline The translation provided is literal (1) & 12 & 34.286 & & \\
\hline The translation provided is weak (.5) & 1 & 2.857 & & \\
\hline No translation is given at all $(0)$ & 3 & 8.571 & & \\
\hline \multicolumn{3}{|c|}{ سال المدرس الطلاب عدة أسئلة اختبارا لمعرفتهم. } & & \\
\hline The translation provided is correct or acceptable(2) & 23 & 65.71 & \multirow{5}{*}{$1.60 \pm 0.65$} & \\
\hline The translation provided is incorrect (1.5) & 3 & 8.57 & & \\
\hline The translation provided is literal (1) & 5 & 14.29 & & \\
\hline The translation provided is weak (.5) & 1 & 2.86 & & \\
\hline No translation is given at all $(0)$ & 3 & 8.57 & & \\
\hline \multicolumn{3}{|c|}{ منح الجندي وساما تقديرا لأعماله العظيمة. } & & \\
\hline The translation provided is correct or acceptable(2) & 14 & 40.00 & \multirow{2}{*}{$-1.31 \pm 0.67$} & \\
\hline The translation provided is incorrect (1.5) & 4 & 11.43 & & \\
\hline
\end{tabular}




\begin{tabular}{|l|c|c|c|}
\hline The translation provided is literal (1) & 11 & 31.43 \\
\cline { 1 - 3 } & The translation provided is weak (.5) & 2 & 5.71 \\
\hline No translation is given at all (0) & 4 & 11.43 & \\
\hline
\end{tabular}

Table (3) shows students' English translations for the five sentences related to the Accusative of Purpose from Arabic to English language. The mean score of the students regarding it (mean $=6.61, \mathrm{SD}=2.56$ ) which was good but acceptable, i.e. when a student got the full mark (10) it means that translation provided for the five sentences was correct or acceptable, so if she got lower than the full mark, surely there are some literal, incorrect or weak translation.

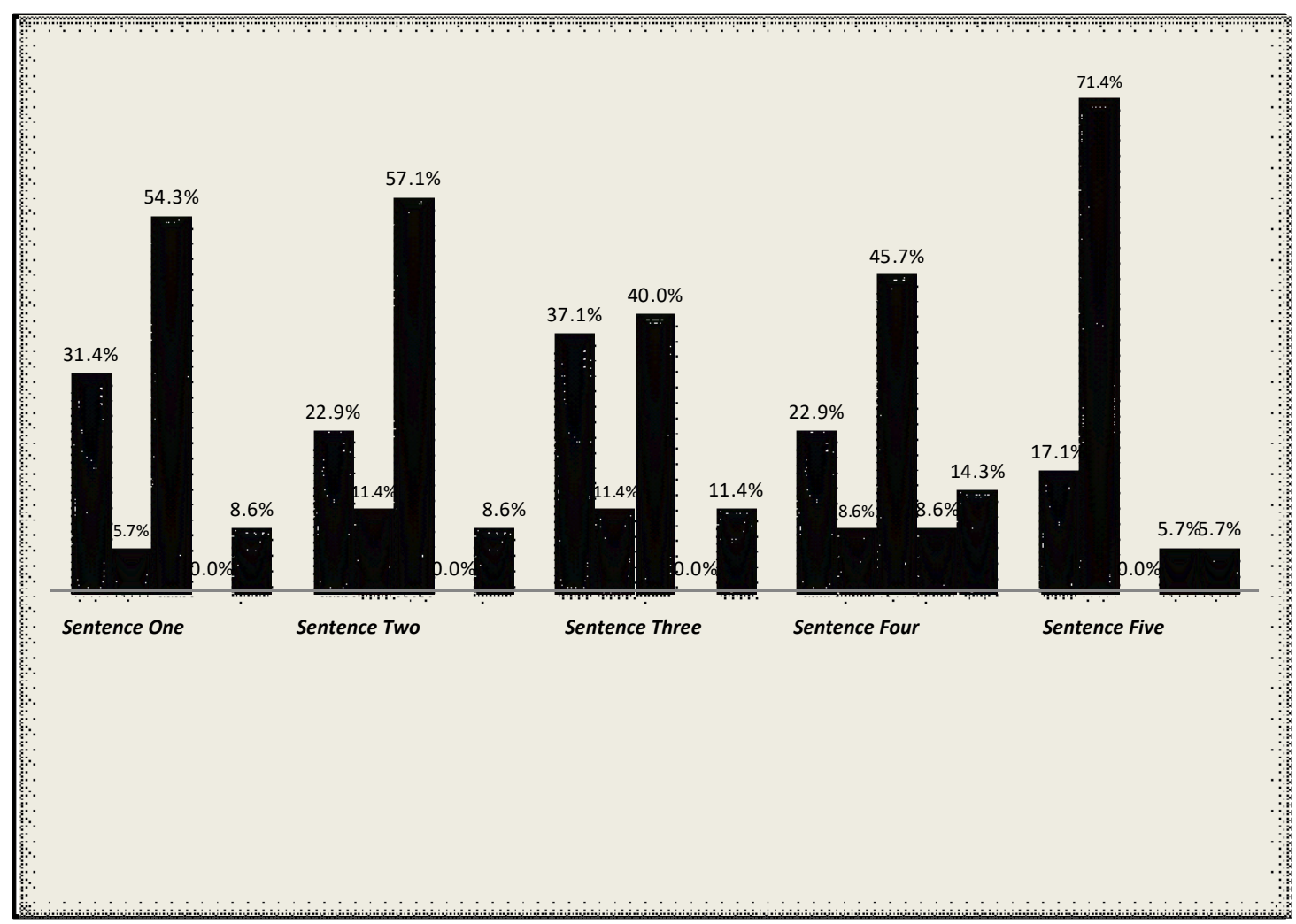

Figure (1) Students' Marks in the Translation Test

Table (4) Mark Interpretation of Accusative of purpose

\begin{tabular}{|c|c|c|c|c|c|}
\hline Mark interpretation & S1 & S2 & S3 & S4 & S5 \\
\hline The translation provided is correct or acceptable (2) & \multicolumn{5}{|c|}{$63 / 175 * 100=36.0 \%$} \\
\hline The translation provided is incorrect (1.5) & \multicolumn{5}{|c|}{$27 / 175 * 100=15.4 \%$} \\
\hline The translation provided is literal (1) & \multicolumn{5}{|c|}{$60 / 175 * 100=34.3 \%$} \\
\hline the translation provided is weak (.5) & \multicolumn{5}{|c|}{$10 / 175 * 100=5.7 \%$} \\
\hline No translation is given at all $(0)$ & \multicolumn{5}{|c|}{$15 / 175 * 100=8.6 \%$} \\
\hline
\end{tabular}

Concerning the students' results in the Accusative of Purpose, table (4) shows that (36.0\%) of the students' translations were correct or acceptable, while $34.3 \%$ were literal, and (15.4\%) were incorrect. However, (8.6\%) of the students did not try to give any translations at all so they got zero, whereas (5.7\%) of the translations provided were weak. 


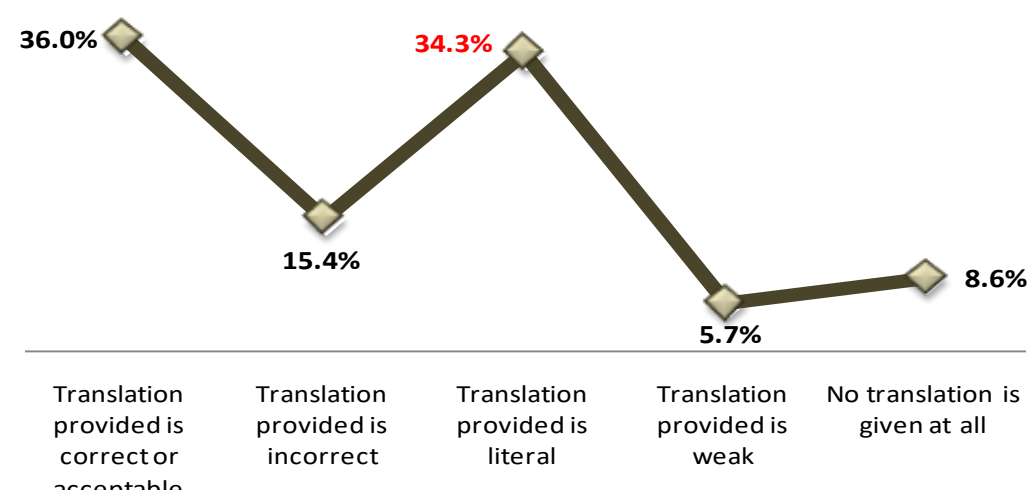

Figure (2) Students' Marks of Translation in Accusative of Purpose

\subsection{Summary of the Students' Results in Accusative of Purpose}

The students did well in this part of the test as the students are familiar with tools of purpose in English such as, "so as to" or "to" or "in order to". The first sentence يجتهدالطالب رغبة في النجاح received the worst translation by the students compared with other sentences of this structure (table 4.7). The reason behind such failure is that students could not compose the sentence well using the familiar purpose tools (so as to, to, in order to). Nevertheless, a gerund can be used in some cases for the translation of this structure such as:

سأل المعلم التلاميذ عدة اسئلة اختبارا لمعرفتهم

This sentence can be translated in two ways: "The teacher asked the students many questions so as / testing their knowledge". Also, idioms or phrases can be used for translating the present category. Most students used the traditional formula "to/ so as to or in order to" because they could not find the correct equivalent منح الجندي وساما تقديرا لأعماله العظيمة".

"The soldier was offered a medal in recognition of his great works".

\subsection{Results and Discussion of the Interview}

Fifteen of the respondents were chosen randomly to be interviewed. The interviews were conducted at College of Science and Humanities in Hurimilla. The interview consisted of nine questions. The results and interpretations were as follow:

1. Do you have any idea about equivalence theories in translation?

Table (4.21) Question Six

\begin{tabular}{|c|l|c|}
\hline Number of Respondents & Response & Percentage \\
\hline 15 & \multicolumn{1}{|c|}{ No } & $100 \%$ \\
\hline
\end{tabular}

All the students admitted that they had not been taught about equivalence, non-equivalence and the strategies of dealing with it. Some of them confessed privately that they had a little idea about these theories.

2. Do you have any idea about Accusative of Purpose?

Table (4.22) Question Six

\begin{tabular}{|c|l|l|}
\hline Number of Students & \multicolumn{1}{c|}{ Students' Answers } & Percentage \\
\hline 10 & Yes & $\% 75 \%$ \\
\hline 5 & No & $25 \%$ \\
\hline Total & & $\% 100$ \\
\hline
\end{tabular}

3. Is it difficult to translate Accusative of Purpose?

Table (4.23) Question three

\begin{tabular}{|l|l|l|}
\hline Number of Respondents & Respondents' Answers & Percentage \\
\hline 13 & Yes & $\% 86,67$ \\
\hline 2 & No & $\% 13,33$ \\
\hline Total & & $100 \%$ \\
\hline
\end{tabular}

4. What are the reasons behind the difficulty of such translation? 
Table (4.24) Question four

\begin{tabular}{|c|c|c|}
\hline Number of Students & Students' Answers & Percentage \\
\hline 7 & Confusing & $\% 46,67$ \\
\hline 2 & Their meaning is not clear & $\% 13,33$ \\
\hline 3 & Have no equivalent & $\% 20$ \\
\hline 2 & No response & $\% 13,33$ \\
\hline 1 & The differences between Arabic and English & $\%, 67$ \\
\hline Total & & $100 \%$ \\
\hline
\end{tabular}

More than $85 \%$ of the interviewed respondents admitted the difficulty of this structure translation. They had studied it during school life, certainly, but many factors accumulate to create this difficulty. About half of the respondents felt confused when translating these categories, while $13.33 \%$ reported not remembering their meaning. The same percentage concluded that they could not find any equivalent.

\section{Conclusion}

The present study aimed at investigating Accusative of Purpose -which is absent in English- through testing the abilities of EFL learners in translating it. Further, this study tried to find the reasons for the confusion EFL learners encounter during translating it. The subjects of the study were undergraduate EFL students (level six, English Department) at Hurimilla College of Science and Humanities, Shaqra University KSA. The shortcomings of the teachers in developing the learners' awareness to the problem areas are glaring. The results of data showed that students dealt with the structure understudy literally or incorrectly when they failed to find the accurate equivalents or did not understand its meaning.The study therefore, concludes that EFL learners face severe difficulty in translating Accusative of Purpose, therefore, they tend to use different strategies such as literal translation and ended up producing incorrect outcomes.

\section{Recommendations}

Based on the results of this study, it is recommended that greater emphasis be placed on Arabic structures that are absent in English and the concept of non- equivalence problems between Arabic and English. Further, teachers need to be encouraged to update their knowledge base on current research into language processing during translation and they be trained in strategies that can ease the pressure for the translators. Core theories of translation should be included in the curriculum of courses that have a translation component. This should be backed up with adequate exposure of the learners in translational practices by using real time language outputs such as movies which not only engage the learners in the learning process but also, place the language in a context.

\section{Limitations of the Study}

This paper was in the nature of a pilot study to understand the pitfalls encountered by professionals and amateurs of translation. The sample size of thirty-five respondents was small and being uni-gendered, the findings may not be freely generalizable. Individual differences are likely to have affected the results. Finally, for dearth of time and resources, the researcher was forced to administer only short and simple language structures for the test. With the recognition that language is about discourse, it is important that greater resources be invested in future studies on these lines and longer texts be analysed to obtain a deeper understanding on the issue. 


\section{References}

[1] Abd Al-Mouain, A. (2004). Al-Mawsoua Al-NahwiyaWa Al-Sarfiya[The syntactic and morphological encyclopedia] Al-Mouyassara .Cairo: IbnSina Bookshop.

[2] Abu-Jarad, Hassan A. (1986). English Interlanguage of Palestinian University Students in Gaza Strip: An Analysis of Relative Clause and Verb Tense. Ball State University PhD Thesis.

[3] Al-Dahdah, A. (2001). Arabic Grammatical Nomenclature. Beirut: Lebanon Library Publishers.

[4] Azziz,Y.Y., Lataiwish, M.S.( 2000). Principles of translation. Libya: University of Garyounis.

[5] Catford, J. C. (1965). A Linguistic Theory of Translation: an Essay on Applied Linguistics, London: Oxford University Press.

[6] Chesterman, A. (1997). Memes of translation. The spread of ideas in translation theory. Amsterdam and Philadelphia: Benjamins.

[7] Chesterman, A., \& Wagner, E. (2002). Can theory help translators: A dialogue between the ivory tower and the wordface. Manchester: St. Jerome.

[8] Mukattash, L. (2001). Some Remarks on Arabic-English Contrastive Studies. Pozan Studies in Contemporary Linguistics. School of English, Pozan: Adam Mickiewicz University.

\section{Appendix}

This Translation Test is for Research Purposes Only

The researcher is going to shed light on the importance of the idea of non- equivalence as the core of translation theory and practice, and how EFL learners aren't sufficiently learned about this basic notion in translation. Translating into the foreign language is always considered more difficult than translating into the native language. To illustrate these points, the researcher is intended to discuss an Arabic structure specifically, the Accusative of Purpose, which has no direct equivalent in English because Arabic and English belong to different language families. Hence, the students always feel confused in dealing with such structures and translate them literally.

ترجمي الجمل الآتية إلى اللغة الانجليزية: -

2.

